\title{
A PEDAgógia ÉS A PSZICHOLÓGIA EGYÜTTÉLÉSI FORMÁI A DEBRECENI EGYETEMEN
}

\author{
BREZSNYÁNSZKY LÁSZLÓ \\ Debreceni Egyetem
}

\begin{abstract}
Az egyetem alapítását követően 1918-ig nem volt önálló pedagógiai katedra, lélektani tanszék pedig csak 1970-től működik. A diszciplínák viszonyát a szakma, a politika és a vidéki egyetem lehetőségei formálták. A változások szakaszra osztva értelmezhetők: a filozófiába és pedagógiába foglaltságtól (Tankó, Mitrovics, Karácsony), a pszichológia fokozatos leválásán át (Kelemen) a térnyerésig (Hunyady, Mészáros, Kovács). Helyi sajátosság: a lélektan a pedagógiai pszichológia révén emancipálódott. Erre épülhetett a pszichológia szak indítása, az intézet kiteljesedése. A változásokat kívánjuk nyomon követni, bemutatni a pedagógia és a pszichológia szervezeti egységeit, fő képviselőit és a viszony jellemzőit az ezredfordulóig. A tanulmány helyi forrásokra és szakirodalmi munkákra támaszkodik.
\end{abstract}

Kulcsszavakः intézménytörténet, 20. század, pedagógia és pszichológia viszonya

After the foundation of the University, there had been no independent professorship in Pedagogy until 1918 and the Department of Psychology started functioning only from 1970. The relationship of these disciplines was formed by the profession, politics, and the opportunities of the rural university. Changes can be interpreted by dividing them into periods: from their inclusion in philosophy and Pedagogy (Tankó, Mitrovics, Karácsony), through the gradual detachment of psychology (Kelemen) until their headway (Hunyady, Mészáros, Kovács). A local specialty: Psychology was emancipated by pedagogical psychology. In other words, the launching of the psychology major and the establishment of the department were based on pedagogical psychology. We trace the changes by presenting the organizational units of pedagogy and psychology, also their main representatives, and the features of their relationship up until the turn of the Millennium. The study is based on local resources and works of special literature.

Keywords: institutional history, 20th century, the relationship between Pedagogy and Psychology

Levelező szerző: Brezsnyánszky László, 4032 Debrecen, Dóczy József u. 30. 1/7.

E-mail: brezsl@gmail.com 
$\mathrm{A}$ debreceni egyetem alapítása a pozsonyival azonos időben, az 1912. évi XXXVI. tc. által előírt módon történt meg. Klasszikus négykarú egyetemet terveztek,

a karok fokozatos kiépítésével. Helyi specialitásnak számított, hogy a bölcsész, a jogi és a teológiai fakultás a Református Kollégium előzményeire épült. A bölcsészkar a humán és a reáltudományi katedrákat foglalta magában. Az új kart az orvosi jelentette. A bölcsészkaron megjelenő lélektannal közel azonos időben jelenik meg az orvosi pszichológia az Orvostudományi Karon (Mudrák 2015). Bár volt és van átjárás a szakterületek között, ez a tanulmány a bölcsészek által képviselt lélektanra koncentrál.

\section{A közös szakasz: egy kézben a pedagógia és a pszichológia}

Azokról az időkről, személyekről és szervezeti formákról emlékezünk meg, amikor és akik a nevelés és a lélektan kérdéseit azonos szervezeti és gondolati rendszerben igyekeztek megfogalmazni és tanítani, ill. azokról, akik új irányt jelöltek ki a tudományterületnek.

A pedagógiának 1918-ig nem volt önálló tanszéke. A katedra betöltéséig a pedagógiai és a pszichológiai kollégiumok hirdetését a filozófia-pedagógia professzora látta el. $\mathrm{Az}$ egyetem az első évtizedekben egyszemélyes tanszékekből állt, amelyeknek egy-egy nyilvános rendes tanár volt a megtestesítője. Munkáját segíthették szakelőadók, lektorok, gyakornokok és habilitált magántanárok.

A filozófia professzora 1914/15. tanévtől hosszú időn át Tankó Béla volt. Kezdetben ő tartotta a filozófiai, pedagógiai és lélektani előadásokat. Teológiát és bölcsészetet tanult, tanári és lelkészi gyakorlattal egyaránt rendelkezett, diplomája előtt ösztöndíjjal angol egyetemre járt. Bőhm Károly tanítványa és követőjeként került Kolozsvárról a debreceni egyetemre. Tudományos munkássága értékelméleti filozófián alapult. Rendszerében egységben látta, kezelte a pedagógia és a lélektan kérdéseit (Fenyő 2004: 20). A fejlődésben fontos szerepet szánt a nevelésnek/önnevelésnek és a lélektan eszközrendszerének.

A Kar meghívással kívánta betölteni a pedagógiai katedrát, Imre Sándort kérték fel, de nem fogadta el. A kiírt pályázatra hárman jelentkeztek. Esélyesnek Mitrovics Gyula és Szelényi Ödön számított. Mitrovics 1917-ben habilitált, magántanárként Tankó tanszékén tanított. Szelényi (1877-1931) pozsonyi teológiai tanárként pályázott. Az egyetem Mitrovicsot fogadta professzorává. A két életpálya a későbbiekben is találkozott. Szelényi 1925-ben habilitált Mitrovicsnál és tartott neveléstörténeti tárgyú magántanári előadásokat 1925-től 1931 őszéig (Vincze-Ugrai 2005).

Mitrovics Gyula (1871-1965) bölcsészdoktori címet 1893-ban szerzett. A Református Kollégium tanáraként pályázott a tanszékre. Nyilvános rendes tanárként 19181941 között folyamatosan töltötte be a vezetői pozíciót. Bölcsészkari dékáni és rektori funkciót is viselt (Vincze 2017). A munkásságának, pedagógiai rendszerének megítéléséről több „tévesnek” bizonyult vélekedés született. Közülük a leginkább elterjedt az utód, Karácsony Sándor által megfogalmazott vélemény, amely szerint Mitrovics csak mellékesen foglalkozott a pedagógia kérdéseivel, mert ezt kívánta tőle a pedagógia professzorának státusa. Szerinte valójában csak az esztétika érdekelte. Ez a személyes konfliktusukból eredeztethető vád vissza-visszatér a róla szóló írásokban (Vaskó 1995; Ádám-Tóth 1994). A konfliktus forrása a katedra utódlása körüli összetűzés. Mitrovics 
rektorként külső (kísérleti pszichológiai munkásságot felmutató) pályázót támogatott Karácsonnyal szemben.

A megítélés erősen leszűkíti Mitrovics munkásságát. Nem veszi figyelembe, hogy a professzor $A$ neveléstudomány alapvonalai címmel megírta a pedagógia alapmúvét (Mitrovics 1933a). Jelentős a pszichológia területen végzett aktivitása pl. a Magyar Pszichológiai Társaságban. Vezetésével empirikus pszichológiai kutatások folytak a tanszéke mellett 1925-ben szervezett Kísérleti Lélektani Intézetben, ahol 1926-1941 között 15 gyakornok dolgozott (Vincze 2017). Közülük néhányan doktoráltak és az oktatásban, kutatásban helyezkedtek el.

A pedagógia és a lélektan kapcsolatáról egyik tanulmányában (Mitrovics 1933b) fogalmazta meg az álláspontját. A tanulmány az alapvonalak egyfajta kiegészítéseként íródott. Azokra a kérdésekre adott érvelő választ, hogy miért látszik a könyv tartalma inkább pszichológiának, mint pedagógiának, és hogy miért nem tekinthető a müve rendszeres és kimerítő pszichológiának? Az egyszerü válasza ezekre, idézzük: „abból indultam ki, hogy a nevelési feladatokkal kapcsolatban alapos pszichológiai iskolázottságra van elsősorban szükség; mintegy pszichológiai gondolkozásmódot kell megszoknunk." (Mitrovics 1933b: 110.) Az érvelés a továbbiakban arra fut ki, hogy a nevelés általa legfontosabbnak tartott céljai (erkölcsi, vallásos, tudományos) és folyamatai mind lélektani összefüggésben értelmezhetők és annak eszközeivel kezelhetők. A pedagógia és a pszichológia kapcsolatát tehát nem diszciplináris alá-fölé-vagy mellérendeltség szempontjából írja le, hanem mint egymásba fonódó tudásokat és cselekvést. Azt is mondhatnánk, hogy az alapvonalak egyfajta korai pedagógiai pszichológiának vagy arra irányuló törekvésnek tekinthető.

Karácsony Sándor (1891-1952) 1942-től 1950-ig volt a tanszék vezetője. A debreceni egyetemen doktorált, majd pedagógiából habilitált Mitrovics professzorsága alatt. 1942-ben nyilvános rendes tanár lett. Sokat oktató, népszerű egyetemi tanár volt. A főkollégiumai átfogó, összegző neveléselméleti, didaktikai, neveléstörténeti és módszertani tematikát követtek. A negyvenes évek végére Karácsony számára elfogadhatatlanná vált, hogy elöírták a témáit. A hatalom pedig a professzor nézeteit és hatását találta veszélyesnek.

Karácsony nem folytatta Mitrovics kísérleti lélektani irányvonalát, a maga alkotta társaslélektani rendszerét képviselte az előadásain és a publikációiban. Pedagógiai tanainak az elméleti megalapozása „multidiszciplináris” jellegű volt. Boros (1990) értelmezésében a szakmai elődöktől eltérően az akkor még néven nem nevezett szociálpszichológia jellegű szemléletmódja alapozta meg pedagógiai rendszerét. Az egyetemen a Társaslélektani Intézet volt hivatva arra, hogy elméleti és gyakorlati tárgyú munkák szülessenek ilyen szellemben. A tanárképzés ebben az időszakban még nem tartozott a tanszék fö feladatainak a körébe, bár Karácsony előadásai és müvei sokat tettek egy újabb szemléletű tanárgeneráció kiművelése érdekében.

Jausz Béla (1895-1974) 1951-1966 között látta el a tanszékvezetői feladatokat. Magyar-német tanári szakon végzett, Eötvös-kollégista volt. Germanisztikából doktorált Debrecenben, ahol lektorként dolgozott. Az 1938-ban induló egyetemi gyakorló gimnázium igazgatója 1944-ig. Kandidátusi címet 1961-ben szerzett. Egyetemi tanárrá nevezték ki. Egy periódusban az egyetem rektora volt. ${ }^{1}$ Jausz elismert iskolai veze-

\footnotetext{
Jausz Béla szakmai pályájáról Vargáné Nagy Anikó (2013).
} 
tőként kapott katedrát, személyes respektusa is megvolt hozzá. Erősen megváltozott körülmények között vezette a tanszékét, ahol a szakmai, politikai erőviszonyok nem támogatták szemléleti iskolák alapítását az ideológiaérzékeny területeken. Hiába tudjuk, hogy személyesen nem azonosult az egyetemre erőltetett „marxista-leninista, vagy még inkább sztálinista" szellemü tankönyvekkel, tananyagokkal, mégis ezeket kellett az előadásain bemutatnia. A visszaemlékezők szerint érdekesek és tartalmasak voltak az órái. Elegáns és nagy müveltségre utaló módon tudta feloldani a való és kellő pedagógia ellentmondásait. Publikációi az esztétikai nevelés és a neveléstörténet témakörében fogalmazódtak. A tanszék tevékenységének súlypontja áttevődött a tanárjelöltek pedagógiai, pszichológiai és gyakorlati felkészítésére. ${ }^{2}$

Kelemen László (1919-1984), tanítóképző intézeti tanár, egyetemi doktori címet Szegeden szerzett 1947-ben, kandidátus (1964), MTA doktor és egyetemi tanár 1969-ben lett, a Pécsi Pedagógiai Főiskola egyik alapítója, a pszichológia tanszékét 1966-ig vezette. Debrecenben lett a Pedagógia Tanszék vezetője 1970-ig. 1970-1981 között az általa szorgalmazott Pszichológiai Tanszéket vezette. Nevéhez füződik a pszichológusképzés (1974) elindítása Debrecenben. Egy periódusban a tanárképzés rektorhelyettese volt, jelentős szerepet vállalt a képzés alakításában. Az iskolai folyamatok befutott kutatójaként kapott meghívást a tanszékre. A vezetőváltás szakmai irányváltást is hozott.

Kelemen időszakában is a tanár és a pedagógia szakosok képzése jelentette a tanszék súlyponti feladatait. Az új vezető magával hozta a korábbi, Piaget szellemiségét hordozó kutatásainak eredményeit és sikerrel illesztette a képzés tartalmaiba. A pedagógiai pszichológia szemléletmódját a lehetőségei határáig iskolává emelte. Kollégái és tanítványai révén a gondolkodásfejlesztés gyakorlati alkalmazását szorgalmazta. A pedagógusok körében számos követőre talált azzal, hogy a tanítás és tanulás folyamatának mindennapi kérdéseire újabb, pszichológiai alapozású magyarázattal és módszerekkel tudott válaszolni.

\section{Együtt a Neveléstudományi - Pszichológiai - Múvelődéstudományi Tanszékcsoportban}

A háború utáni első években megváltozott az egyetem szervezeti rendje, szellemisége, az oktatói kar összetétele és a hallgatók létszáma. Az orvosi és teológiai kar levált, a jogit szüneteltették. A KLTE-en két kar szerveződött (BTK, TTK). ${ }^{3}$ Az 1960-as évek végén a bölcsészkaron belül az „intézetesedés” mint az integráció eszköze tette aktuálissá a Neveléstudományi Tanszék szervezeti átalakulását. Több külső és belső változtatási szándék találkozott és ütközött ebben az ügyben. Kelemen László tervezeteket készített a témában, szerette volna elérni, hogy önálló lélektani tanszék jöjjön létre. A pedagógiai és a népművelési szakterületen is ébredtek olyan személyes ambíciók, hogy önálló tanszék vezetői lehessenek.

Az ügy 1968. december 17-én került napirendre a Kari Tanács (KT) rendkívüli ülésén. Kelemen László december 10-én készült felterjesztését tárgyalták a tanács tagjai.

Tanszékén pszichológiát oktató munkatársak is voltak: Ádám Péter, Nádudvari Imréné, Surányi Gábor.

Kossuth Lajos Tudományegyetem karai: Bölcsészettudományi és Természettudományi. 
Az előterjesztés ${ }^{4}$ fó érvei arról szóltak, hogy a szakmai, tudományos korszerűsödés a pszichológia terén önálló szervezeti keretet, tanszéket igényel; a három szakterületet egybefogó tanszék irányítása nehézkes, a pénzügyeket már külön-külön kezeli az egyetem; megvannak a jelöltek az egyes tanszékek élére.

A Kari Tanács vitájában felszólalók aggályokat fogalmaztak meg. Mindenekelőtt a személyi feltételek hiányára hivatkoztak, halasztást javasoltak, és azt szorgalmazták, hogy bizottság vizsgálja meg a Kar többi tanszékének az igényeit az újabb tanszékek felállítását illetően. A hozzászólásokból nem derül ki egyértelmüen, hogy az oktatók létszámára és felkészültségére vagy a vezetők személyére utaltak-e, amikor a hiányt említették. A még osztatlan neveléstudományi tanszéken 13 oktató és 3 egyéb munkatárs dolgozott. Közülük 1 egyetemi tanári, 4 docensi, 7 adjunktusi és 2 tanársegédi besorolásban. Négyen oktattak pszichológiai tantárgyakat, öten pedagógiai és négyen népművelési kollégiumokat vezettek. Az akkori viszonyok között ennyi oktató együtt, egy tanszéken soknak tűnt, bár a feladatok is sokrétüek voltak. A Kari Tanács végül nem hozott döntést. A dékán azt javasolta, hogy bizottság vizsgálja meg a többi tanszék igényét, és a Kar várja meg az egyetem új müködési szabályzatát. Ezzel gyakorlatilag a rektor hatáskörébe utalta az ügyet. A folytatásban 1970 őszére az eredeti tanszéket három részre bontották. Létrejött a Pszichológiai Tanszék Kelemen László vezetésével, tanszéki státust kapott a népművelés Durkó Mátyás irányításával. A pedagógiaoktatás feladatait ellátó egységet Petrikás Árpád vezetésére bízták. A három önálló tanszék a Neveléstudományi-Pszichológiai és Művelődéstudományi Tanszékcsoport keretében továbbra is együttműködést vállalt. A tanszékcsoport vezetője 1981-ig Kelemen László, majd Vaskó László docens lett.

A tanszékek összetett oktatási feladatokat láttak el. Rövidesen három szakért lett felelős a tanszékcsoport (pedagógia, pszichológia, népmüvelés szak). A tanárképzés pedagógiai és pszichológiai modulját mindkét karon a pedagógia és a lélektan oktatói tanították.

\section{A pszichológia szervezeti karrierje}

A döntés nyomán az egyetem szervezetében a pedagógia és a pszichológia elkülönült egymástól. Az adott tudomány képviselete, oktatása és kutatása az önálló tanszékek felelősségévé vált. A vállalás és a kockázat is a pszichológia oldalán volt a súlyosabb.

Az új debreceni pszichológiai tanszék esetében a szakmai szétválás sajátosan alakult. Kelemen László kutatásai, publikációi ugyanis alapvetően pedagógiai indíttatásúak voltak, nevelési, oktatási, tanulási jelenségek és folyamatok megértéséhez és kezeléséhez lélektani megközelítésben keresték a válaszokat. Az ő szakmai világképében ilyen módon egységben voltak jelen lélektani és neveléstani jelenségek. Ez a szaktudományos megközelítés tette rokonná a munkásságát a gyermektanulmányozásnak és a fejlődésléktannak az ötvenes évek második felétől már legitim, a sztálini időszakban még üldözött hazai és külhoni nagyjaihoz (Nagy László és köre, Harsányi István, Mérei Ferenc, Jean Piaget, Hans Aebli). Az irányultság jól követhető Kelemen müveiben és hivatkozásaiban (Kelemen 1981).

\footnotetext{
BTK Jegyzőkönyvek: 1968. dec. 17. KT rendkívüli ülés, melléklet. A Neveléstudományi Tanszék intézetté szervezése. Gépelt kézirat.
} 
A pszichológia története a Debreceni Egyetemen c. tisztelgő kiadvány azt az alaphangot üti meg, amit majd a későbbi hasonló írások is követnek, hogy az önálló tanszék létrehozása egy korszak végét jelenti a pszichológia helyi történetében (Ádám-Tóth 1994). Ez szervezeti értelemben aligha vitatható, bár legalább ennyiben kezdetnek is nevezhető. Más megközelítésben viszont a professzor távozásával zárult le egy időszak. Kelemen átfogó szemléletmódja a pedagógia és a lélektan érintkezési felületére vonatkozott. Szerintünk ilyen értelemben a korszakhatár nem 1970, az önálló tanszék alapítása, de nem is 1974, a pszichológusképzés elindítása, hanem a professzor 1981-ben történő távozása az egyetemről.

Az önálló tanszék alapításával és a szakos képzés indításával sokat változott a szaktudomány egyetemi státusa. A lélektani tárgyak oktatását a tanárképzésben a pedagógiai pszichológia tanszéke vette át. A szakos képzés igényei a differenciálódás útjára terelték a tanszéket.

\section{A pszichológusképzés indítása}

$\mathrm{A} z$ önálló tanszék felállításával szinte azonos időben tervezetek születtek az általános pszichológia szak indítása és a tanszék intézetté fejlesztése érdekében. A szakindítást illetően négy tervezetet ismerünk Kelemen László tollából. Az első 1970. 10. hó 12-én, a második 1972. 11. hó 4-én keltezett, a harmadik 1973. 12. hó 10-én íródott (ÁdámTóth 1994: 1., 2., 4. melléklet). ${ }^{5}$ A negyedik a BTK Kari Tanács ülésének melléklete.

Az első két javaslatban a képzés indításának szükségessége kap hangsúlyt, a növekvő szakemberszükséglet a tanácsadásban, iskolai életben, médiában. Fontos érv, hogy Budapesten kívül nem folyik pszichológusképzés, a fóvárosban képzettek pedig ritkán vállalnak máshol állást. Az első felvetésben több képzési forma jelenik meg. Nappali tagozaton tanár szakkal párosítva (idegen nyelv, biológia, matematika) vagy harmadik, ún. c) szakként. Személyi feltételként 7, majd 15 új státust jelölnek meg a tervezetek.

Az 1972 őszén írt javaslat előrelépésről tanúskodik, hangneme is határozottabb. A szövegben megjelennek az intézményen belüli és a főhatóságoknál lefolytatott egyezkedések eredményei. Ebben a szövegben jelenik meg először az MSZMP KB Agitációs Propaganda Bizottságának határozatára történő hivatkozás, melynek nyomán a Művelődésügyi Minisztérium az ötéves egységes pszichológusképzés mellett foglalt állást. Ezek a dokumentumok a későbbiekben normaként müködtek. Érvként használták valamilyen fejlesztés, privilégium elérése érdekében. A tényleges tartalom viszont nem jelent meg a kari vagy egyetemi anyagokban, de a minisztériumi leiratban sem. Ebben az időszakban az MSZMP KB Tudománypolitikai Irányelvek (1969. 06. 26.) jelentették az útmutatást a tudományos élet és a kutatás fejlesztésének stratégiájáról (Bakó Á. et al. 1978). ${ }^{6}$

Gépelt kéziratok 1. Javaslat a pszichológia szak bevezetésére a Kossuth Lajos Tudományegyetemen (7); 2. Javaslat a pszichológus képzés bevezetésére a KLTE-en (4); 3. A cím ugyanaz. (18). Az említett kötet mellékletében közölt dokumentumok forrásértékét gyengíti, hogy a fénymásolatok egyikén sem szerepel kézjegy, aláírás, pecsét.

6 Az Irányelvek szövegében a pszichológia fejlesztésére egy megjegyzést találtunk. Idézzük: „szükségessé válik a szociológia területén több kutatócentrum létesitése, megfelelö pedagógiai kutatóbázis kiépitése, a pszichológiában pedig a kutatások helyes struktúrájának megteremtése" (Bakó Á. et al. 1978: 30). 
A felülről érkező bíztatás megtette hatását. A Művelődési Minisztériumból Polinszky Károly miniszterhelyettes levélben ${ }^{7}$ kéri a KLTE rektorát, Bognár Rezsőt, hogy vizsgálja meg a pszichológusképzés indításának helyi feltételeit, és azt, milyen további fejlesztések mellett indítható a szak (12-15 fös felvételi létszámmal) az 1974/75. tanévben.

Kelemen professzor 1973 decemberében fogalmazott javaslatában - válaszul - tételesen ismerteti a tanszék aktuális személyi összetételét (8 oktató és 1 ösztöndíjas kutató), indokolja, miért van szükség partneroktatókra. Összesen 10 új státus létesítését kezdeményezi az 1974-77 közötti időszakban. A szükséges tárgyi feltételek között tanári szobák és laboratóriumi helyiségek szerepelnek.

A szakindítás tárgyában a negyedik - általunk ismert - javaslat a Kari Tanács 1974 júniusában tartott IV. rendes üléséhez csatolt $A z$ új, ötéves, egyszakos, egységes pszichológusképzés célja, tantervének alapelvei, óraterve, tanulmányi és vizsgakövetelményei c. dokumentum. ${ }^{8}$ A felterjesztés a címében megjelölt tematikát követi. A korábbiaknál részletesebben ismerteti azokat a munkaterületeket, ahol a végzett pszichológusok iránt igény mutatkozik. Alapozó képzést ígér, de megjelöli a speciális gyakorlati képzés lehetséges irányait is (nevelési és pályaválasztási tanácsadás, gyermekvédelem, klinikai munka, felső- és középfokú oktatás, kutatómunka).

$\mathrm{A} z$ igényeknek megfelelően a képzés három alapozó irányt céloz meg: munka-, klinikus- és pedagógiai lélektant. A tervezet hangsúlyozza, hogy a tervezési folyamat szakmai szervezetek, szakértői bizottságok közel ötévnyi munkáján alapul. A főhatóságok kontrollját végigjárta. Itt is említésre kerül a párt agitprop bizottságának támogató állásfoglalása. A tanterv tartalmi kérdéseiben a tudományok közti együttműködés elve hangsúlyos.

A tanácsülés vitáján a támogató hozzászólások mellett több gond is megfogalmazódott. Lesz-e elegendő oktató a szak indításához? Van-e garancia arra, hogy a személyi fejlesztés nem a Kar többi tanszékének rovására történik? A tanterv kisebb módosításaira tett javaslatot a dékán és a tanszékvezető. Az első két félév tantervét elfogadta a Tanács. A többi félév tervezetét átdolgozásra visszaadta. A dékán egyben emlékeztette a tanács tagjait, hogy a szakindítás maga nem volt tárgya az ülésnek, mivel arról már főhatósági döntés született. Az eredmény lényegében egyezett Kelemen professzor szándékaival. Az egyszakos pszichológusok képzése útjára indulhatott Debrecenben.

Jelen tanulmány szempontjából nem hagyhatjuk említés nélkül, hogy a vitában a neveléstudomány vezetője támogatta a szak indítását. Annak ellenére azonban, hogy a szakindítás ekkor még a közös tanszéki csoport keretén belül történt, ahol a felek a feladatok kölcsönös támogatása mellett álltak ki, a tervezetekben nem szerepel olyan tárgy, amihez a társtanszékek oktatóira számítottak volna.

\section{A Pszichológiai Intézet}

A pszichológia szak indítása és ezzel együtt a bölcsészkari fejlesztésekhez képest rapid bővülés tovább távolította egymástól az 1970-ben tanszékcsoportba „integrált” tanszékeket. Ebben a konstrukcióban egyik tanszék sem érezte jól magát. A mun-

\footnotetext{
MM iktatószám: 69931/1973.XII.

8 BTK jegyzőkönyvek: KT 1974. 06. 25-én tartott IV. rendes ülés.
} 
katársi létszámot illetően nagy egyenetlenség alakult ki. A pszichológiai tanszék a szétváláskor magával vitte a pszichológiát oktatókat. Az újabb alkalmazások több forrásból adódtak: frissen végzett pedagógia szakosokkal, ${ }^{9}$ félállású átoktatókkal a budapesti ELTE-ről és az MTA intézetéből, kutatói státusú munkatársakkal (6 fô) és óraadókkal (13 fö) ${ }^{10}$ gyarapodott a tanszék. Kelemen professzor utolsó debreceni éveire a létszám 23 före növekedett, beleértve az 5 egyéb munkatársat (Ádám-Tóth 1994). Összehasonlításul említhetjük, hogy az 1970-1980 közti időszakban a neveléstudományi tanszék a kutatói státusokkal együtt 7-ről 15 főre emelkedett. A tanszékcsoporton belüli aránytalanság egyre feszültebbé tette az együttmüködést. Mindhárom tanszék önállóságra törekedett, keresték az alkalmat a kiválásra, magasabb státusú szervezeti egységgé szerveződésre. A Kar és az Egyetem sem tudott megfelelő megoldást találni. Kelemen gyakran felvetette, hogy a pszichológiai képzést szakmai okokból a TTK-ra kellene áttelepíteni, ahol intézeti keretben működtek a tanszékek. A BTK nem pártolta a „kiugrás” kísérletét.

$\mathrm{A} z$ önálló intézet létrehozására a nyolcvanas évek közepén érett meg a helyzet. A Kari Tanács 1984-ben tárgyalta ${ }^{11}$ a Pszichológiai Intézet létrehozása c. napirendi pontot. Az ülésen meghívottként jelen volt Hunyady György, aki 1980 őszétől félállásban lett tanszékvezető. Az előterjesztés bizottsági előkészítő munka alapján készült. ${ }^{12} \mathrm{Az}$ intézet létrehozásának legfőbb érvei a megnövekedett létszámból adódó helyzetre, a Magyar Tudományos Akadémia Tudománypolitikai Bizottságának támogató állásfoglalására ${ }^{13}$ és a diszciplináris tagozódás igényére támaszkodott. A tanszék létszáma 1984-re 37 före gyarapodott, ami messze meghaladta a BTK-n megszokott 6-8 fős tanszékek személyi állományát. A pszichológia kiugró létszáma és finanszírozása így nem csupán a tanszékcsoporton belül, hanem a karon is feszültségeket generált. A szkeptikus tanácstagok nem támadták a tervezetet, de garanciát kértek arra, hogy nem a többi egység rovására történik a pszichológia további gyarapítása és elhelyezése. Az előterjesztők úgy nyilatkoztak, hogy számítanak a minisztérium támogatására, mert a Kar és az Egyetem önmagában nem vállalhatja az intézet létrehozásának terhét. A Kari Tanács végül az intézet létrehozására, de fokozatos kiépítésre tett javaslatot. Az előterjesztésben felvázolt öt intézeti tanszékből kettőt (a Pedagógiai Pszichológiait és az Általános Lélektanit) terjesztette tovább. A dékán a döntés előtt kettős nyomás alá került, mivel tagja volt a minisztériumi előkészítő bizottságnak, ugyanakkor jól érzékelte a vezetésére bízott és a kollégáiból álló bölcsészkar hangulatát.

Az Intézet ügye az Egyetemi Tanács (ET) elé került. 1984. 09. 06-án, az I. rendkívüli ülésen, majd 1985. 02. 28-án, az V. rendes tanácsülésen. Az őszi előterjesztés a Kari Tanács anyagát tartalmazta, amelyet Orosz István kiegészítésekkel látott el. Az ET 1985. február végi ülésén a különfélék között szerepelt az intézet ügye. Ekkorra már valójában megszületett a minisztérium döntése az alapításról. A vita itt fóleg a társtanszékek jövőjéről szólt.

\footnotetext{
9 Balogh László, Bugán Antal, Cserhalmi Magda, Füri Rajmund, Kálmánchey Márta.

10 Köztük Kiss Tihamér (1905-2005), Piaget-tanítvány, óraadó és kutatói feladatokat is ellátott.

11 1984. 05. 24-én az V. rendes ülés.

12 BTK jk: KT 1984. 05. 24. V. rendes ülés melléklete: 13 gépelt oldal, Orosz István dékán aláírásával.

13 Forrásra hivatkozás nélkül.
} 
Tóth (2004) kézirata úgy írja le az intézet alapításának történetét, mint amit a BTK és az ET kevéssé támogatott, inkább késleltetni kívánta. A legfőbb ellenállás viszont a társtanszékek részéről volt tapasztalható - írja. Szerinte Hunyady kitartó erőfeszítésének köszönhetően jutott az ügy révbe. Forrás megjelölése nélkül idéz Hunyady György egyik leveléből: „A Pszichológiai Intézetröl lefolytatott vitákban csak azt tapasztalhattuk, hogy a pedagógiai, illetve felnöttnevelési társtanszékek szószólói leplezetlen önérdekböl belytelenítik a pszichológusok kiválását a jelenlegi formális keretböl."14

Nincs okunk a levélben megfogalmazottakban kételkedni, sőt bizonyára elhangzottak hasonló csípős szavak a másik fél részéről is, de megjegyezzük, hogy a tanácsüléseken a társtanszékek hivatalos és meghívott képviselői inkább támogatásukról nyilatkoztak, viszont - talán „önérdekből” - mindig hozzátették, hogy a társtanszékek ügyét egyidejüleg rendezni szükséges. Erre a felvetésre csak 1985-ben született válasz. Az egyetemi döntéshozók nem támogatták azt a javaslatot, hogy a Nevelés- és a Müvelődéstudományi külön-külön intézeti státust kapjon. Azt is elutasították, hogy a tanárképzésben játszott szerepe alapján a neveléstudomány tanszéke rektorközvetlen egységgé legyen. Táblacserés „megoldás” született: intézetté nevezték át az egykori tanszékcsoportot, de már a pszichológus testület nélkül.

Ami Hunyady György szerepét, érdemét illeti az intézeti rang kivívásában, vitathatatlan, de az is, hogy a megoldáshoz az erő kívülről, felülről érkezett. Az egyetem mellékszereplővé vált az ügyben. A szokásos pártállami forgatókönyv érvényesült. A párt megmondta, a főhatóság erőt vitt bele, az egyetem végrehajtotta. Természetesen az egyetem is nyert az új és divatos képzéssel, az idővel megnövekedett hallgatói létszámmal és bevételekkel. Az utóbbiak feletti rendelkezés idővel komoly viták forrásává lett.

$\mathrm{A} z$ új intézet vezetője kívülről érkezett, Mészáros István idegélettani professzor személyében, aki 1985-től nyugdíjazásáig töltötte be az igazgató szerepét. ${ }^{15}$ Kovács Zoltán majd Bugán Antal követte a vezetői székben.

$\mathrm{A} z$ intézet rapid növekedésével nehézségek is jelentkeztek. Nem sikerült pl. saját tanítványi köréből intézetvezető professzort nevelni. Nem minden káderfejlesztés járt tartós sikerrel. A növekedés és a tanszékek számának további emelkedése félállású vezetőket és személyi ellentéteket is szült az intézetvezetésért folyó versenyben. Kovács Zoltán igazgatósága idején a "lejáró” és a helyi oktatók között vált feszültté a helyzet, ami végül az igazgató és hívei távozásával megoldódni látszott (Tóth 2014: 26-27.) Az általunk áttekintett időszakon túl, 2005-ben a személyi és szakmai ellentétek az intézet szakadásához vezettek. Az utolsó közös intézetigazgató, Bugán Antal öt munkatársával együtt az integrált nagyegyetem Népegészségügyi Karához, a Magatartástudományi Intézethez csatlakozott.

\section{A neveléstudományi katedra feladatvállalásai és viszonya a pszichológiához}

A Neveléstudomány Tanszéket Petrikás Árpád (1928-1999) vezette az 1970-1991 közötti időszakban. Leningrádi aspiráns volt 1959-1963 között, itt kandidált. A nevelő

14 Idézet a forrás megjelölése nélkül.

15 Erre az időszakra esik Kürthy Tamás (1921-1994), az aacheni egyetem Felvidékről származó professzorának díszdoktorrá avatása. A professzor Bagdy Emőke meghívására vett részt a mentálhigiénés képzés indításában és szponzorálásában. 
közösség funkciói témában írt dolgozatával (1982) indított MTA doktori folyamat sikertelen próbálkozásnak minősült. Nyugdíjazásáig egyetemi tanárként vezette a tanszéket. ${ }^{16}$

A tanszék létszáma a pszichológus kollégák távozásával csökkent. A nyugdíjazottak helyére fiatalabb, jórészt pedagógia szakot végzettek kerültek. A hetvenes évektől kutatói csoport működött az MTA Pedagógiai Kutatócsoport (PKCS) debreceni „alcentrumában” (1974-1976), majd a Neveléstudomány fejlesztését szolgáló 6. számú pedagógiai kutatások főirányának finanszírozásában (1976-1980). A pályázati időszak végén a kutatók közül néhányan a tanszék állományába kerültek. A vizsgálatok az iskolai közösségfejlesztést és a helyi nevelési rendszerek értelmezését célozták.

A kilencvenes évek elején Vaskó László, majd Orosz Gábor vezette a tanszéket. Az egyetemi vezetés MTA doktorátussal rendelkező egyetemi tanárt kívánt a tanszék élére állítani, pályázat útján.

Kozma Tamás nyerte el a vezetői megbízást részfoglalkozásban, majd teljes státusban az 1995-2004 közötti időszakban. Ekkor kapott lendületet a PhD-képzés a filozófus, pszichológus, szociológus egységek összefogásának eredményeként. Kozma Tamás 1995-2010 között vezette a neveléstudományi doktori programot. Tanszékvezetői hitvallása értelmében igyekezett a katedrát a szaktudomány szolgálatába állítani. A jelentős kutatóintézeti múlttal rendelkező vezető gyors és hathatós átalakítás ötleteivel érkezett, kevésbé érzékelte, hogy az egyetem nem a rövid távú célfeladatokra szerveződött, hanem folyamatos képzések és kutatások ellátására. Szívesen lemondott volna akár a tanárképzés kiszolgálásáról, ha így erőket szabadíthat fel a nevelésszociológia javára. Ennek az elképzelésnek a doktori képzés biztosított kedvező terepet. A tanszék nyert is és veszített is a képzési súlypontok átrendeződésével. A kutatómunka a doktori hallgatók bevonásával eredményesebbé vált, főleg a felsőoktatási témák területén. Háttérbe szorult viszont a tanár szakos, az alapképzés és a későbbi rendszer szerinti mesterképzés. Egy új szak alapítása és indítása nem járt sikerrel. A tantervek, tantárgyak az oktatáskutatás irányába átstrukturálódtak. Az iskolateremtés szociológiai irányt vett.

Leegyszerüsítve azt mondhatjuk, hogy a tanszék profiljában és a pedagógia hagyományos problémáinak értelmezésében fordulat állt be. Csakúgy, mint Kelemen László idejében, új megközelítést kaptak a nevelés és oktatás jelenségei, folyamatai. Kelemen a pszichológia körébe vonta, Kozma pedig a szociológia, az oktatáskutatás terepévé tette azokat. A tanszéket kutatói bázisként hasznosította.

\section{A pedagógia és a pszichológia viszonyának alakulása a képzésben, kutatásban}

Ami a szakmák, a szervezeti egységek és a kollégák egymáshoz való viszonyát illeti, nehéz hiteles és jól dokumentált képet adni. A szervezetkutatások (Kozma 2004) és sokan mások szerint az egyetem olyan szerveződés, amelyben a formális és informális viszonyok erősen hierarchizáltak. Hivatali és elismertség szerinti rangsorok hálózzák be a tanárok, kutatók világát. Esetünkben a diszciplináris távolodás kétségtelenül vetél-

16 Részletes, kissé szépített szakmai életrajzát Tölgyesi (2002) munkájában olvashatjuk. Ld. még: http:// w.fmg.hu/sites/default/files/egykori_tanarok_diakok/egykori_tanarok/petrikas_arpad.pdf 
kedést is hozott magával. A fölény felmutatására a vitákban, tantárgyfelosztási egyezkedésekben láthattunk példákat.

A pszichológia diverzifikálásával egyre nehézkesebbé vált a szakok közti átoktatás. Az együttműködés helyett az elzárkózás és a saját körben történő fejlesztés felé alakultak a viszonyok. A pszichológiai intézet többnyire hárította a pedagógia szak lélektani tárgyainak oktatását, mivel a saját kurzusaik magasabb óraszámban és részletesebb tematikával futottak. Ebből adódott, hogy a saját szak érdekében a pedagógián idővel pszichológus munkatársakat alkalmaztak. A pszichológiai intézet pedig saját erőből oldotta meg a tanárjelölt pszichológus hallgatók pedagógiai tárgyainak oktatását. Hogy ebben az elzárkózásban a gazdaságosság vagy a szakmai önérzet, esetleg a szakmai fölény játszotta-e a nagyobb szerepet, ennek megválaszolása nem a feladatunk.

A tanárképzésben az együttmüködés a kilencvenes évektől gördülékenyebbé vált. Köszönhetően annak, hogy a Pedagógiai Pszichológiai Tanszék saját profiljának tekintette a modul pszichológiai tantárgyainak oktatását, ahogy a Neveléstudományi Tanszék a pedagógiai tárgyakét. A tanárképzés folyamatát pedig az illetékes rektorhelyettes mellet létrejött Tanárképzési Kollégium koordinálta valamennyi tanár szak esetében.

A kutatások a vizsgált időszakban leginkább a tanszékeken szerveződtek. Kevés példát találhatunk társtanszékek közötti együttmüködésre.

Összegzésként megállapíthatjuk, hogy a pedagógiai és pszichológiai nevet és különféle felfogásokat képviselő kollégiumok a debreceni egyetem alapítása óta jelen voltak a bölcsészkari tantárgykínálatban.

Kezdetben a filozófiai kurzusokhoz társulva. Az önálló pedagógiai tanszék alapításával a pedagógia professzorának illetékességi körébe kerültek a nevelési és lélektani kollégiumok.

Az önálló pszichológiai tanszék létrehozása új pályát nyitott e szakterület számára. A szakindítás és az intézeti rang eléréséhez a tanszék mindenkori vezetői jelentős külső segítséget kaptak. Javukra fordították a 70-es, 80-as évek pártállami mechanizmusait. A pszichológia és az egyetem is profitált a fejlesztésekből.

A neveléstudomány jó ideig a marginalizálódás veszélyével küzdött. Vezetői vagy a tanárképzésben igyekezetek a tanszéket legitimálni, vagy szakmai irányváltással próbálkoztak a képzésben és a kutatásban.

\section{IRODALOM}

Ádám P. \& Tóth L. (1994) A pszichológia története a Debreceni Egyetemen. In: Kovács Z. (ed.) A debreceni pszichológusképzés 20 éve. Debrecen, KLTE Pszichológiai Intézet. pp. 5-108.

BAKó Á. et al. (1978, eds) A MSZMP KB Tudománypolitikai alapelveinek végrehajtása és további feladatok. Budapest, Kossuth.

Boros D. (1990) Boros Dezső kiadatlan dolgozatai Karácsony Sándor pedagógiájáról és a tanárképzésröl. Debrecen, KLTE.

Brezsnyánszky L. (2007, ed.) A „Debreceni Iskola” neveléstudomány-történeti vázlata. Budapest, Gondolat.

Fenyő I. (2004) Tankó Béla. In: Brezsnyánszky L. \& Fenyő I. (eds) A debreceni iskola. Debrecen, pp. 17-25.

Kelemen L. (1981) Pedagógiai Pszichológia. Budapest, Tankönyvkiadó. 
Kozma T. (2004) Kié az egyetem? Budapest, Új Mandátum.

Mitrovics Gy. (1933a) A nevelés alapvonalai. Debrecen-Budapest, Csáthy Könyvkereskedés R.T.

Mitrovics Gy. (1933b) A pedagógia és a pszichológia kapcsolata. Magyar Paedagogia, Vol. XLII. Nos 7-8. pp. 110-122.

Mudrák J. (2015) Pszichológia a Debreceni Tudományegyetemen a XX. század első felében. Magyar Pszichológiai Szemle, Vol. 70. No. 3. pp. 579-595.

Tóтн L. (2014) A pszichológia története a Debreceni Egyetemen. Kézirat.

Tölgyesi J. (2002, ed.) Petrikás Árpád bibliográfiája. Veszprémi Egyetem Neveléstörténeti Füzetei 2. Veszprémi Egyetem.

VARgÁné Nagy Anikó (2013) Jausz Béla a pedagógus professzor. Az 1919-1959 közötti szakmai életút elemzése. PhD-értekezés (kézirat). Debrecen.

VAskó L. (1995) Mitrovics Gyula oktatáspolitikai és pedagógusképzési elképzelései. Debrecen, KLTE.

Vincze T. (2007): Mitrovics Gyula, az egyetemi professzor. In: Brezsnyánszky L. (2007, ed.): A „Debreceni Iskola” neveléstudomány-történeti vázlata. Budapest, Gondolat. pp. 104-117.

Vincze T. (2017) Alkotás és iskolateremtés. Pedagógia tanszék a Tiszántúl egyetemén 1918 és 1941 között. Debrecen, Egyetemi Kiadó.

Vincze T. \& Ugrai J. (2005) Szelényi Ödön. (Tudós tanárok - tanár tudósok sorozat.) Budapest, OPKM.

A cikk a Creative Commons Attribution 4.0 International License (https://creativecommons.org/licenses/ by/4.0/) feltételei szerint publikált Open Access közlemény, melynek szellemében a cikk bármilyen médiumban szabadon felhasználható, megosztható és újraközölhető, feltéve, hogy az eredeti szerző és a közlés helye, illetve a CC License linkje és az esetlegesen végrehajtott módosítások feltüntetésre kerülnek. (SID_1) 